Article

\title{
Study of Urban Greenery Models to Prevent Overheating of Parked Vehicles in P + R Facilities in Ljubljana, Slovenia
}

\author{
Alenka Fikfak ${ }^{1, *(D)}$, Kristijan Lavtižar ${ }^{1}$, Janez Peter Grom ${ }^{1}$, Saja Kosanović ${ }^{2}$ and \\ Martina Zbašnik-Senegačnik ${ }^{1}$ \\ 1 Faculty of Architecture, University of Ljubljana, Zoisova Street 12, 1000 Ljubljana, Slovenia; \\ kristijan.lavtizar@fa.uni-lj.si (K.L.); janez.grom@fa.uni-lj.si (J.P.G.); martina.zbasnik@fa.uni-lj.si (M.Z.-S.) \\ 2 Department for Architecture, Faculty of Technical Sciences, University of Priština in Kosovska Mitrovica, \\ Kneza Miloša Street 7, 38220 Kosovska Mitrovica, Serbia; saja.kosanovic@pr.ac.rs \\ * Correspondence: alenka.fikfak@fa.uni-lj.si; Tel.: +386-1200-0777
}

Received: 2 June 2020; Accepted: 23 June 2020; Published: 24 June 2020

check for updates

\begin{abstract}
Parking in park-and-ride $(P+R)$ facilities on the outskirts of a city reduces the traffic inside the cities and follows the principles of sustainable mobility. However, large paved (asphalt) surfaces create urban heat islands (UHI). This causes the temperature to rise in vehicles during full-day parking, which has a negative effect on comfort level and driving performance. This study was conceptualized as two-stage research. The first (preliminary) stage dealt with the measurement and analysis of temperature data at two nearby open parking lots in the city of Ljubljana, one of which was the main research spatial area, P + R Barje (L1), and Trnovo parking (L2), which was used for comparison in the first-stage research. In the preliminary research, we underlined the problem of long-term parking in parking areas exposed to heatwaves (HW). The second stage involved the studying of greening schemes in $\mathrm{P}+\mathrm{R}$ facilities, which would allow for optimal shading during parking. Advanced 3D and 4D models using ENVI-met and LEONARDO software were developed, which assessed the parking surfaces and the areas of optimum outdoor comfort. Shading by greenery was adopted in this paper, as the strategy aimed at improving the conditions by modelling different variants of greening the parking lot L1.
\end{abstract}

Keywords: park-and-ride ( $\mathrm{P}+\mathrm{R})$; urban heat island (UHI); overheating in vehicle; thermal comfort in vehicle; drivers' performance; urban greenery

\section{Introduction}

Urban areas are becoming the main target of climate change [1]. The effects of global warming and climate change are expected to be exaggerated in cities, particularly with respect to extreme heatwave events [2-5]. The phenomenon of urban climate must be comprehended in the local and regional contexts, in which all dynamics and impacts are undertaken in relation with the expansion of urban sprawls. Both the diminishing of green urban areas and the increase of artificial surfaces are aggravating the impact of heatwaves (HW). The greatest HW temperature increases are expected in Central European cities, whereas cities such as Ljubljana, Prague, and Zagreb will experience a significant rise in HW [4]. A number of studies, including observational, modelling, or both, focusing on the micro to the meso-scale, have investigated the effectiveness of using different mitigation strategies to reduce the urban heat island (UHI) in various cities. Strategies aimed at increasing urban vegetation in urban areas are referred to as green infrastructure (GI) strategies [6-10].

Urban areas are characterized by a large proportion of artificial surfaces, such as concrete and asphalt, which absorb and store more heat than natural vegetation, leading to the UHI effect [11]. Measures to 
reduce UHI usually target the improvement of thermal comfort in cities $[3,7,10,12]$, particularly in residential areas $[6,8,13-16]$, and involve extensive greening schemes. Here, changes in traffic flow play a special role by introducing measures to encourage sustainable urban mobility. These include putting initiatives in place to reduce the number of vehicles in city centers by introducing park-and-ride $(P+R)$ parking facilities on city outskirts. $P+R$ is a system of nodes, which spatially, organizationally, and often also in pricing, combines parking areas with public passenger transport stops. They are intended for parking personal vehicles on the outskirts of the city or as close as possible to the origin and transferring to public transport (bus or train), taking the passengers to the city or city hubs [17]. Parking organization in large parking lots along major arterial roads and the use of public transport and other forms of sustainable mobility facilitates the arrival to work, while also improving the air in the center and reducing the needs for parking areas in the city. On the other hand, the concentration of cars in parking areas that (mostly) lack greenery brings the UHI effect [18] to the city outskirts as well.

This study does not address the implications of extensive parking areas on micro locations, but, rather, it focuses on the problem of high temperatures in the vehicles parked in parking areas exposed to sunlight during summer when people return to their cars after work and drive home. Owing to the evolution of technologies, we have become increasingly used to a balanced climatic comfort, which increases the sense of living discomfort outdoors. Increased ambience temperatures deteriorate the physical well-being of people causing problems, such as "heat stress in the form of heat syncope, thermal exhaustion, cardiovascular stress, cardiorespiratory diseases and heat stroke" $[19,20]$. At extreme air temperatures, humans are at higher risk of, for example, heart attacks and asthma, thereby increasing morbidity rates among vulnerable population groups [21].

The greenhouse effect leads to a temperature rise in the vehicle even at relatively low temperatures of outside air and little clear sky [22]. The latter is due to the transmission spectrum of glass, which transmits the sun's radiation of shorter wavelengths. Sunlight, therefore, heats up the incident surfaces inside the vehicle, which emit long wave thermal radiation due to the increased temperature. This radiation is not transmitted by the glass, leaving heat "trapped" inside the vehicle. McLaren et al. [23] measured the temperature rise inside a vehicle on 16 sunny days (with ambient temperatures ranging from $22{ }^{\circ} \mathrm{C}$ to $36^{\circ} \mathrm{C}$ ). Even on a cooler day with an outside ambient temperature of $22{ }^{\circ} \mathrm{C}$, the internal temperatures reached $47^{\circ} \mathrm{C}$. Marty et al. [24] measured temperatures in vehicles under varying weather conditions and in various seasons and found that when cars were exposed to sunshine even during winter, the interior temperature rose up to $30^{\circ} \mathrm{C}$, and in spring and autumn, up to $60^{\circ} \mathrm{C}$, while in summer, interior temperature extremes of up to $90^{\circ} \mathrm{C}$ were recorded.

A parked vehicle typically heats up very quickly, which first affects the thermal comfort of the driver and passengers. However, even more dangerous than the personal thermal discomfort is the correlation between high temperatures and a lower alertness of the driver, while consequences can be fatal. Driving demands a high level of concentration from a driver; therefore, optimal physical conditions must be met. Heat stress can produce detrimental effects on motor response and some cognitive deficiencies may be attributed to decreased motor performance [25]. Mental task is differentially sensitive to thermal stress [26] and reaction times are longer for hyperthermic subjects [27]. Based on the measured temperatures and humidity [25], with increased temperatures, drivers' performance losses of up to $50 \%$ are predicted even for relatively simple tasks, such as keeping the vehicle on a straight course. Performance losses in excess of $75 \%$ are predicted under the most extreme thermal conditions for demanding tasks, such as correctly identifying a signal and reacting in due time [25].

Studies have found compelling evidence of lower alertness, implying a higher chance of missing signals, and slower responsiveness, implying longer reaction times and higher accident rates. In the study by Wyon et al. [28], the alertness and driving performance of drivers driving for one hour on public roads was measured (in sections with speed limitations of 50,70, 90, and $110 \mathrm{~km} / \mathrm{h}$ ); the drivers were randomly assigned to one of two thermal conditions $\left(21^{\circ} \mathrm{C}\right.$ or $\left.27^{\circ} \mathrm{C}\right)$. They found that the negative effect of heat stress on vigilance was statistically significant. At $27^{\circ} \mathrm{C}$, the overall proportion of missed signals was $50 \%$ higher and response times were $22 \%$ longer than they were at $21^{\circ} \mathrm{C}$. These effects of 
heat were significant and proportionally greater in the second half-hour for subjects $<40$ years and for speeds below $60 \mathrm{~km} / \mathrm{h}$ (i.e., in city traffic). The latter finding suggests that heat may have increased arousal, and there was some indication of a redistribution of attention away from the most peripheral signals at the higher temperature.

Urban greenery can help to regulate urban microclimates. Green areas are actually the most efficient element that help to reduce the UHI effect [28,29]. Adding more urban trees, parks, gardens, wetlands, and green roofs within urban areas is generally referred to as the implementation of GI strategies. Trees mitigate air overheating, offer shade, and increase the feeling of humidity with their breathing leaves. Vegetation is the necessary element of parking areas, with trees and green areas in between the parking places, as only this can prevent the overheating of concrete, asphalt, and metal surfaces to intolerable temperatures. Importantly, the specificity of $P+R$ sites is the following: the car is parked at the $\mathrm{P}+\mathrm{R}$ site for several hours, while we return to it from a hard day's work from overheated spaces. In any case, the city is a much friendlier urban place if high-quality green mobility is taken care of. Increasing the vegetation land cover could considerably reduce surface temperatures at parking lots [20,30]; trees of a height of 5-10 $\mathrm{m}$ help to control the overheating of surfaces [18]. Gillner et al. [31] recommend decreasing the thermal load in urban areas for future tree planting by choosing species with high cooling potential. The location of trees at a parking lot has an influence on solar exposure reduction. Bajsanski et al. [18] developed and demonstrated an algorithm that optimizes the location of trees, aiming to provide the maximum overshadowing of parking lots.

The main purpose of this paper was to underline the problem of the rate of temperature rise in parked vehicles in large parking areas exposed to sunshine and propose solutions with an optimal introduction of vegetation as protection against the sun. The research of the relation between built and open (void) spaces refers to the effects of surface and atmospheric UHI. The case study of Ljubljana in Slovenia offers an opportunity to explore spatial and microclimate qualities referring to sustainable mobility systems. Besides the pioneering exploration of the aforementioned conditions at open $\mathrm{P}+\mathrm{R}$ lots in the city of Ljubljana, the novelty of the presented study is the research methodology, which represents a combination of several types of methods, from ex ante problem observation, to experimental work in situ, to computer simulations and modeling, to an ex post multicriteria comparative analysis of the obtained results.

\section{Materials and Methods}

\subsection{Case Study}

The city of Ljubljana is the largest urban area in Slovenia; $14.0 \%$ of the total Slovenian population-i.e., 289,830 inhabitants-reside in the city of Ljubljana [32]. The natural conditions in the Municipality of Ljubljana (MOL) carry environmental risks, especially regarding floods and earthquakes. The weather in Ljubljana is conditioned by the city's geographical position in a vast basin extending from Slovenia's pre-Alpine to karst areas. In the study of 571 European cities [4], Ljubljana is one of 28 cities in the top 20\% changes in both flooding and HW maximum temperature indices.

Ljubljana was awarded the 2016 European Green Capital title [33], which gives it the designation of a sustainable city. An important criterion for this flattering title was the progress made by the city in terms of greening schemes, sustainable mobility, and energy performance. In the application portfolio, the following information regarding green areas was provided: there are $542 \mathrm{~m}^{2}$ of public green areas per capita, more than $46 \%$ of the urban area is covered by native forest, $75 \%$ of all surfaces are green, and the Path of Remembrance and Comradeship $(34 \mathrm{~km})$ is the longest city tree line with 7000 trees [33].

The first $P+R$ facility in Ljubljana was built on the Dolgi Most location in 2001 [17]. Currently, there are five active $\mathrm{P}+\mathrm{R}$ city sites, and $\mathrm{P}+\mathrm{R}$ Barje represents the largest one. It is positioned three kilometers away from the city center and equipped with elements of sustainable mobility. The Transport Policy, adopted by MOL in 2012 and included in the Integrated Traffic Strategy of Ljubljana Urban Region (LUR) in 2018, puts emphasis on the restriction of personal motor traffic and the change of 
travel habits "with improving the distribution of mobility by one third of journeys by public transport, one third by bicycle and on foot and one third by personal vehicle" [34]. The sixth Ljubljana's P + R facility will be completed during 2020 in Stanežiče [35].

In relation to the meaning of $\mathrm{P}+\mathrm{Rs}$ for urban planning, Žaucer et al. emphasize the following: "the multifunctionality of the space, the mixing of uses and the appropriate interweaving of functions enable the $P+R$ node to be alive, pleasant and safe regardless of the part of the day, time of year or day of the week. A successful P $+\mathrm{R}$ hub is an urban area integrated into a settlement. It is a public space, which is also a place to meet, socialize and create mutual ties in the local community" [17]. Until today, however, Ljubljana has not developed a model for $\mathrm{P}+\mathrm{R}$ areas, and their evolution rather follows other spatial interventions in the city. There is no clear position on whether multifunctional $\mathrm{P}+\mathrm{Rs}$ are more appropriate, nor does there exist guidelines for the multifunctional combining of the importance of locations. On the other hand, the significance of existing $\mathrm{P}+\mathrm{Rs}$ in the city can be proved by analyzing the public traffic network. The largest $\mathrm{P}+\mathrm{R}$ Barje is directly linked to the highway and the city ring, thus, covering the arrival to Ljubljana from the Western to the Southwest regions of Slovenia, as well as the LUR area tied to this part. This represents more than one third of the territory of Slovenia. Furthermore, $\mathrm{P}+\mathrm{R}$ Barje is positioned beside road traffic connections with Italy and Croatia.

Most of the publicly available parking areas in Ljubljana are surrounded, at least on two sides, with green areas, which indirectly beneficially reduce overheating. The construction of additional $P+R$ parking areas on the city outskirts should reduce the occupancy of parking areas in the center and the pressures in peak periods, as estimated by MOL. The P + R occupancy rate in Ljubljana depends on several factors, such as the trends of using the highway system, the changing of the local transport, the price of city parking areas, access to desired locations, etc. $\mathrm{P}+\mathrm{Rs}$ are locations of static activities: i.e., cars are parked for $8-10 \mathrm{~h}$ nowadays on the average workday, plus the outbound and inbound travel to the site. Any car parked here absorbs the quality of the urban climate through external surfaces of sheet metal. At the same time, the degree of overheating is returned inside and directly affects human well-being.

For this research case study, P + R Barje in Ljubljana (Figure 1) was selected (area of 208 ha, constructed in 2015). A particularity of this parking area is the soft Barje ground, which necessitated the installation of a concrete foundation slab with a surface area of $13,000 \mathrm{~m}^{2}$, supported by 1117 piles. All the necessary installations were added: sewage, public lighting, optical connection for Urbanomats, and a Bicikelj self-service bike rental point.

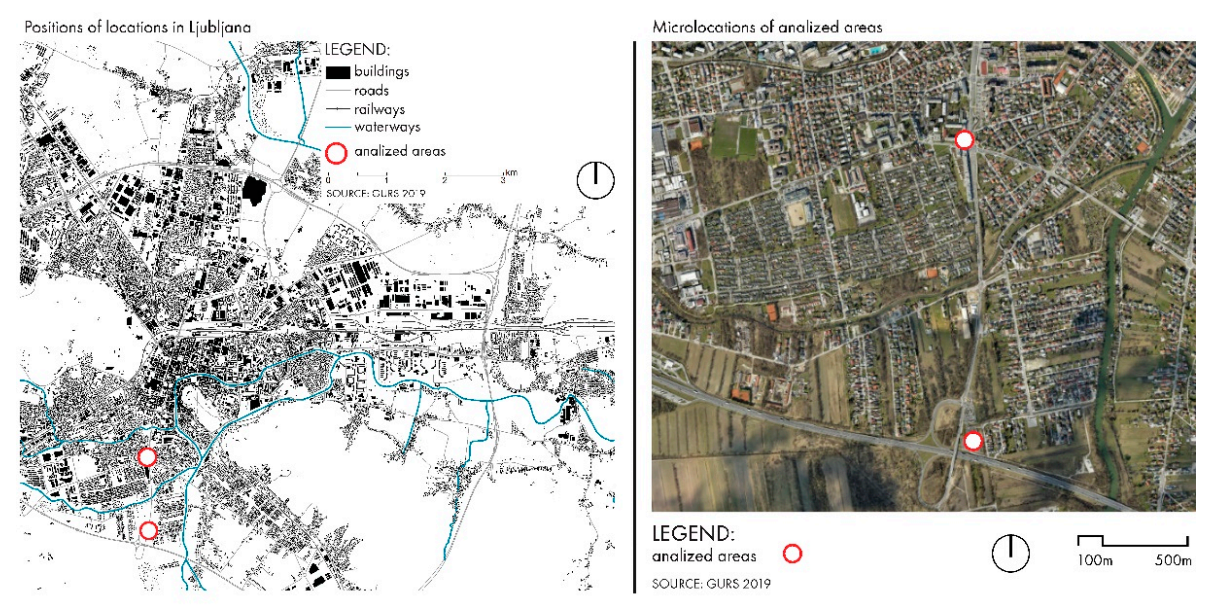

Figure 1. Ljubljana. L1—park-and-ride (P + R) Barje, L2-Trnovo parking (Source: [36]).

\subsection{Methods and Tools}

The materials and tools for this study consisted of surveys of key precedents, detailed mapping, and modelling using ENVI-met. The study implemented morphological and typological research methodologies, field observations, and on-site analyses, with the data used as follows: 
- Geomorphological data by the Surveying and Mapping Authority of the Republic of Slovenia were used [36]. Analyses of geomorphological (topography, reliefs, terrain type, and climate conditions), and mapping of landscape characteristics were conducted. Spatial data were mapped using GIS ESRI ArcGIS software (ArcMap version 10.3.1) for visual representations and analyses.

- Thermal satellite imagery was done based on Landsat 8 data obtained from the satellite thermal infrared sensor (TIRS) [37]. The Landsat 8 satellite (launched as the Landsat Data Continuity Mission-LDCM on 11 February, 2013) mission continues the acquisition of high-quality data that meet both NASA and USGS scientific and operational requirements for observing land use and land change [37]. We used Landsat 8 images for the production of the thermal map. The images were processed using Esri ArcGis Software, which was transformed in a way to calculate the temperature for each pixel separately by converting the raw bands into top of atmosphere radiance (TOAr). The temperature calculations were done with the Raster calculator tool, which calculated the temperature values for each pixel separately. For the visual representation, the initial $30 \times 30 \mathrm{~m}$ grid was resampled using the ArcMap Resample tool to a $1 \times 1 \mathrm{~m}$ grid. A bilinear resampling technique was used.

- $\quad$ Remote sensing images: Google satellite images of P + R Barje (L1) and Trnovo parking (L2) [38] (Figure 2) and orthophoto images from the remote sensing database, sheet orthophotos DOF050 2018 [36] were used. Remote sensing data were used for a manual line-art drawing of the spatial situation in Autodesk AutoCAD 2019. Furthermore, we elaborated a spatial representation of the $\mathrm{P}+\mathrm{R}$ Barje parking area. Sheets of DOF050 images covering the area were combined and clipped to the study area using ESRI ArcGIS 10.6 and the ArcToolbox clip tool.

- The ENVI-met [39] database of materials and 3D vegetation was used in ENVI-met SCIENCE in ENVI-met SPACES for the manual drawing of the cell map in the size of $100 \times 100 \times 20$ pixels. We mapped the existing vegetation and surfaces using input cartographic data. The selection of materials and surrounding vegetation reflected the actual conditions in the area. The choice of vegetation in the parking area varied in the variant solutions.

- Temperature measurements were taken in vehicle cabins at parking areas P + R Barje (L1) and Trnovo parking (L2) under various temperature and weather conditions (June-August, 2018).

- In situ observations and analysis were conducted with fieldwork and photographic recording (May, 2018-August, 2019).

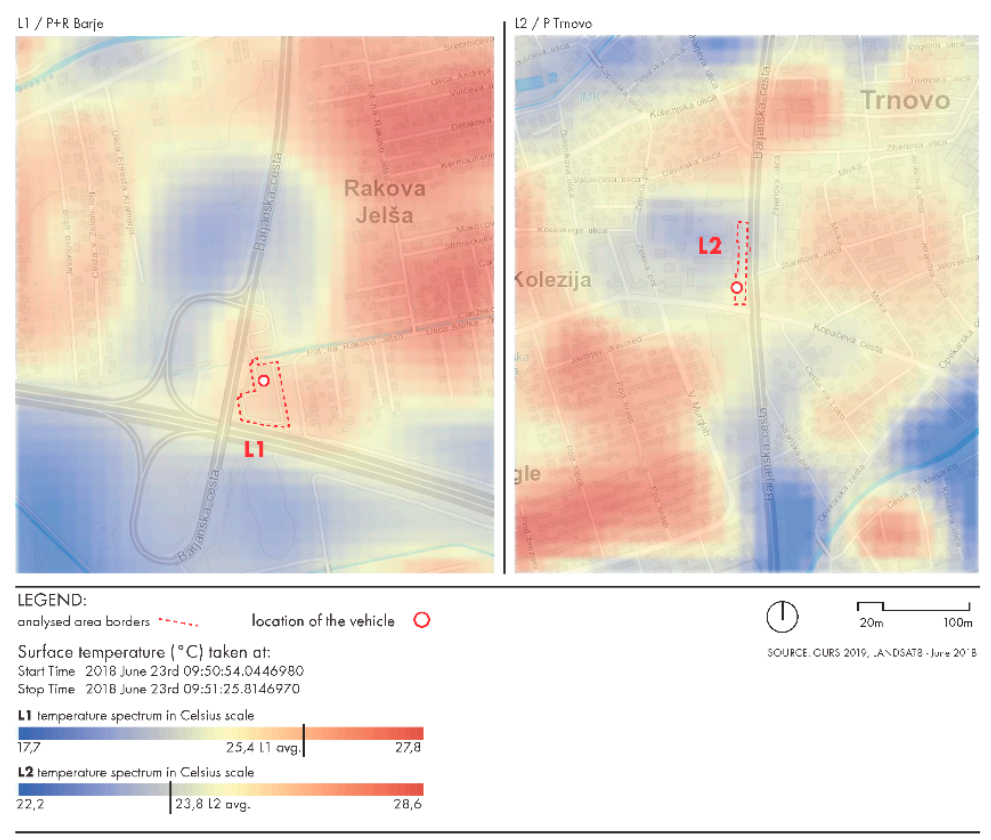

Figure 2. Ljubljana. Urban heat islands (UHI) in L1-P + R Barje, L2-Trnovo parking. 


\subsection{Preliminary Research}

The study on ambient temperatures inside vehicles in large parking areas exposed to sun was done in the preliminary research step to identify the relationship between UHI areas and open parking spaces. The preliminary research included the study on temperature measurements and thermal comfort. When checking the temperature conditions, we compared two parking areas that were $1300 \mathrm{~m}$ apart. The parking areas had the same orientation and other boundary conditions, but they differed in terms of their greening schemes. Parking area L1 contained trees that had no canopy and did not provide protection against sun, so the vehicles were exposed to direct solar radiation all day long; L2 had dense trees and the vehicles were in the shade throughout the day (Figure 3).

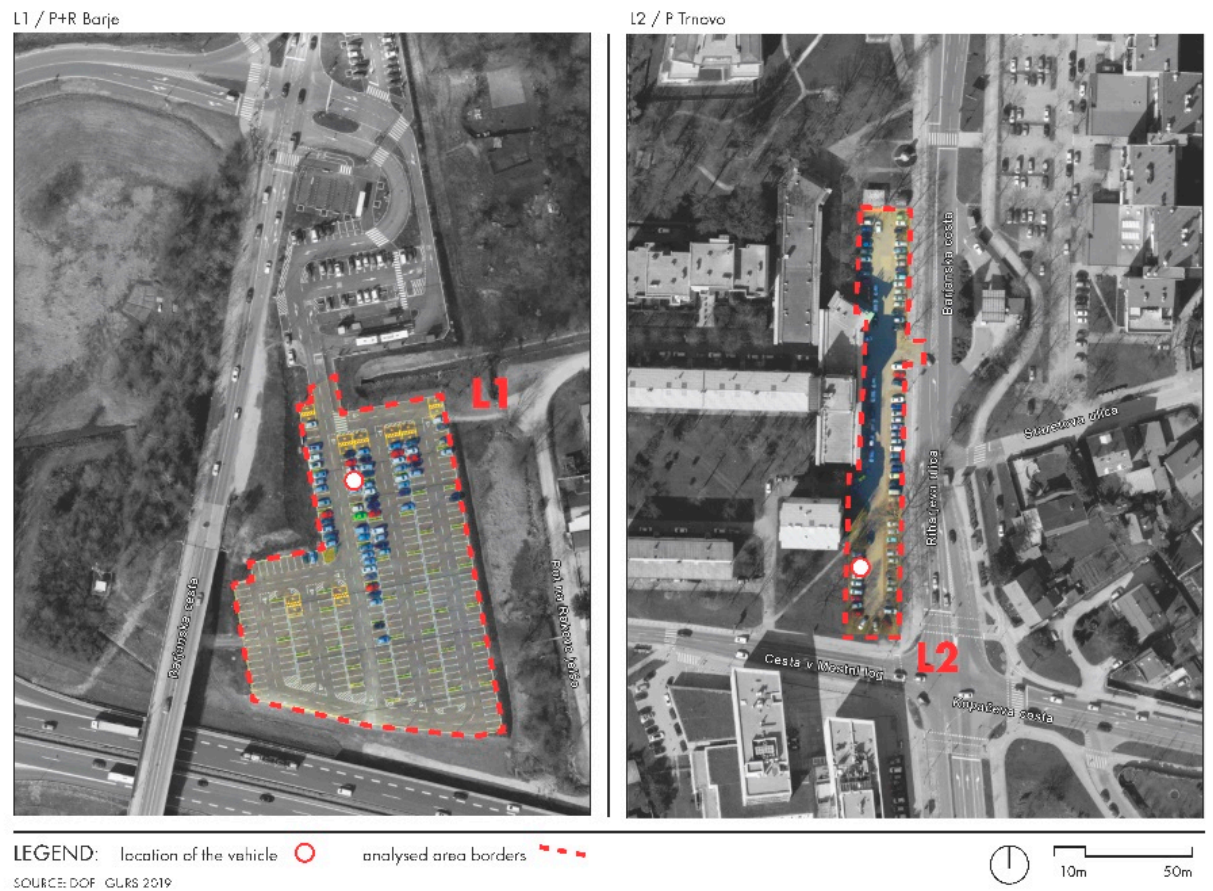

Figure 3. Location of the vehicle (preliminary research). UHI in L1-P + R Barje, L2-Trnovo parking.

Two cars with similar characteristics were used in the study: Peugeot 208, white-colored, with dark grey textile seats. In both cars, the windows were closed at all times. The vehicles were parked in both parking areas at the same time: (1) outdoor parking area L1 without trees, where the vehicle was parked in direct sunlight, with no shade, and (2) parking area with trees L2, where the vehicle was parked in the shade of trees all day long (Figure 3). The orientation of parked vehicles was the same in both parking areas. In line with the objective of this paper, warm days with various temperatures and cloud coverage were selected: i.e., when temperatures inside vehicles rise significantly. The windows in the vehicles were closed during the parking. Other studies also have found that cracking windows by a few centimeters does not contribute to continuous cooling, as temperatures stay high inside vehicles after several hours of parking under direct sunlight [22].

During the parking, the outside and vehicle cabin ambient temperatures were taken at the height of the driver's head. During the night, the vehicles were parked in a garage (sheltered area) at a distance of 2200 and $3500 \mathrm{~m}$, respectively, from the selected parking areas (a 6- and 8-min drive, respectively), for about $6 \mathrm{~h}$ each night.

To focus on the worst-case scenario, the preliminary study went underway in summer months, which is when the temperatures in vehicles rise the most [26]. The temperature was measured upon arrival to the parking area and before the departure. Days with a different cloud coverage during parking were selected. Only air temperatures were measured, although the comfort level in a 
vehicle is also influenced by the relative air humidity and air speed. Under such high thermal stress, air temperature has the highest influence on a person's comfort level and driving performance.

\subsection{Elaboration of Greening Scheme Models at $P+R$ Sites}

This study focused on P + R Barje (L1) (Figures 2 and 3), analyzing the various scenarios of introducing vegetation as a protection against sun. The scenarios for developing the greening schemes were investigated using microclimate simulations by applying a numerical model at the micro level. The ENVI-met software allowed for the simulation of the progression of various thermodynamic parameters in a 3D space (cell grid, where each cell is $2 \times 2 \times 2 \mathrm{~m}$ ) between morphology-microclimate and vegetation. The programmatic model considered the physical considerations based on the principles and laws of fluid mechanics and thermodynamics used to calculate three-dimensional wind fields, turbulence, air temperature and humidity, radiation flows, and pollutant dispersion [40,41]. The central part of the P + R Barje parking area is in the South of Ljubljana, at latitude 46 and longitude 14.5. The model was presented at a $3 \mathrm{D}$ level used to simulate interactions between the surface area, vegetation, and atmosphere in urban areas in a rectangular grid with a variable accuracy and $3 \mathrm{D}$ distances in $x, y$, and $z$ directions. The parking area extended in a $150 \times 200 \mathrm{~m}$ area, which was transferred into a digital model of $100 \times 100 \times 20$ cells. This resolution allowed for the analysis of the interactions between the various buildings, surface, and plants for various scenarios in a $24 \mathrm{~h}$ period.

Parking spaces are organized in the West-East direction with green areas, with trees parallel to the parking spaces. The parking area is located in an open plain area surrounded by a low lawn in the South and Western sides, asphalt surfaces in the North, and a green area and trees in the Eastern side. Based on microclimate parameters, structure, and the composition of the ground surface, ENVI-met [39] was used to simulate alternative scenarios of vegetation and the organization of parking spaces.

The digital surveying groundwork data for the parking areas were obtained from the [36]. For the simulation model, relevant microclimate data from the nearest weather station, Ljubljana Bežigrad [42], were used in order to study how urban microclimate develops under the current conditions and how vegetation improves the thermal comfort at the $\mathrm{P}+\mathrm{R}$ Barje parking area. We used the graphic interface ENVI-met SPACES for the manual plotting of the site as cells, along with the value parameters containing information on plants, land cover, and materials. All cartographic data first had to be collected and used for input into the ENVI-met graphic editor, where the basic databases were used in the first stage as generic values of the initial simulations (for the following elements: soil and surface, vegetation, buildings, and greenings). The maps with localized 3D data were then transferred into the model, where new input data on the atmosphere for modelling the context were added, which was the second stage of simulations. All the input data used were taken from the day when the temperatures were measured: i.e., 29 June 2018. The first phase was intended for the accurate modelling of the static context, while the second phase included some variables connected to surface and atmospheric temperature, such as solar radiation duration, wind direction, humidity, etc. The variant solutions were limited to the distribution of trees and green walls of a height of $3 \mathrm{~m}$. Green canopies were not included in the simulation because of the software limitation of spatial representations with cells and the available size of the model with $100 \times 100 \times 20$ cells.

\section{Results}

\subsection{Preliminary Research Outcome}

In June, 2018, Ljubljana had seven hot days with temperatures exceeding $30^{\circ} \mathrm{C}$ and 20 days with temperatures of $25^{\circ} \mathrm{C}$ and above [43]; in July, 2018, there were 10 days with temperatures above $30^{\circ} \mathrm{C}$ and 24 warm days above $25^{\circ} \mathrm{C}$ [44]; and there were 18 days with temperatures above $30{ }^{\circ} \mathrm{C}$ and 27 days with temperatures $25^{\circ} \mathrm{C}$ and above in August, 2018 [45]. Together, with the position of open parking lots L1 and L2 in the dynamic UHI map of Ljubljana (Figure 2), the conducted measurements confirmed that the temperature in the vehicle parked at the sun-exposed lot reached values that caused 
overheating and jeopardized the health of vehicle users. Precisely, a comparative temperature analysis on two parking lots for the period 29 June 2018-15 August 2018 revealed the following:

- the difference between outdoor morning temperature at locations L1 (strongly sun-exposed P + R Barje) and L2 (well-landscaped Trnovo parking), measured at 8.00 a.m., was small (from $0.4{ }^{\circ} \mathrm{C}$ min. to $1.4{ }^{\circ} \mathrm{C}$ max.);

- the temperature in the cabin of the sun-exposed vehicle at L1 was significantly higher than the temperature in the vehicle in the shade at L2 (both were measured at 2.00 p.m. during the whole examination period);

- $\quad$ on July 7 at 2.00 p.m., the temperature in the cabin of the vehicle parked at the exposed lot L1 was high even in partly cloudy weather;

- $\quad$ on 29 June, 3 July, and 4 July at 2.00 p.m., the temperature in the cabin of the car parked at L1 reached a dangerous level despite the more favorable external conditions (cloudy weather and milder outside air temperature) (Table 1);

- at 2.00 p.m. on the excessively hot day of 7 August, the temperature inside the car parked at L1 was extremely high, thus, endangering the health and well-being of vehicle users.

Table 1. Air temperature measurements inside and outside vehicle cabins in parking lots L1 (area without the shade) and L2 (shaded area) in warm days with varying cloud coverage.

\begin{tabular}{|c|c|c|c|c|c|c|c|c|c|}
\hline \multicolumn{5}{|c|}{ P + R Barje L1 } & \multicolumn{5}{|c|}{ Trnovo Parking L2 } \\
\hline Weather & Day & Hour & OUT. & INS. & Weather & Day & Hour & OUT. & INS. \\
\hline$m$ & \multirow{2}{*}{ 29.6.2018 } & 8.00 a.m. & $16.4^{\circ} \mathrm{C}$ & $20.9^{\circ} \mathrm{C}$ & $m$ & \multirow{2}{*}{ 29.6.2018 } & 8.00 a.m. & $16.9^{\circ} \mathrm{C}$ & $21.2^{\circ} \mathrm{C}$ \\
\hline & & 2.00 p.m. & $29.1^{\circ} \mathrm{C}$ & $38.4^{\circ} \mathrm{C}$ & & & 2.00 p.m. & $20.7^{\circ} \mathrm{C}$ & $26.2^{\circ} \mathrm{C}$ \\
\hline & \multirow{2}{*}{ 3.7.2018 } & 8.00 a.m. & $21.3^{\circ} \mathrm{C}$ & $26.3^{\circ} \mathrm{C}$ & & \multirow{2}{*}{ 3.7.2018 } & 8.00 a.m. & $20.3^{\circ} \mathrm{C}$ & $23.6^{\circ} \mathrm{C}$ \\
\hline & & 2.00 p.m. & $28.9^{\circ} \mathrm{C}$ & $48.8^{\circ} \mathrm{C}$ & & & 2.00 p.m. & $25.9^{\circ} \mathrm{C}$ & $33.8^{\circ} \mathrm{C}$ \\
\hline & \multirow{2}{*}{ 4.7.2018 } & 8.00 a.m. & $19.8^{\circ} \mathrm{C}$ & $25.6^{\circ} \mathrm{C}$ & & \multirow{2}{*}{ 4.7.2018 } & 8.00 a.m. & $18.4{ }^{\circ} \mathrm{C}$ & $23.4^{\circ} \mathrm{C}$ \\
\hline & & 2.00 p.m. & $25.3^{\circ} \mathrm{C}$ & $44.9^{\circ} \mathrm{C}$ & & & 2.00 p.m. & $24.4^{\circ} \mathrm{C}$ & $25.8^{\circ} \mathrm{C}$ \\
\hline है & \multirow{2}{*}{ 5.7.2018 } & 8.00 a.m. & $19.2^{\circ} \mathrm{C}$ & $25.1^{\circ} \mathrm{C}$ & ह & \multirow{2}{*}{ 5.7.2018 } & 8.00 a.m. & $19.7^{\circ} \mathrm{C}$ & $25.1^{\circ} \mathrm{C}$ \\
\hline & & 2.00 p.m. & $31.5^{\circ} \mathrm{C}$ & $53.5^{\circ} \mathrm{C}$ & & & 2.00 p.m. & $31.8^{\circ} \mathrm{C}$ & $33.5^{\circ} \mathrm{C}$ \\
\hline & \multirow{2}{*}{ 2.8.2018 } & 8.00 a.m. & $25.1^{\circ} \mathrm{C}$ & $26.2^{\circ} \mathrm{C}$ & & \multirow{2}{*}{ 2.8.2018 } & 8.00 a.m. & $25.1^{\circ} \mathrm{C}$ & $26.1^{\circ} \mathrm{C}$ \\
\hline & & 2.00 p.m. & $33.0^{\circ} \mathrm{C}$ & $46.5^{\circ} \mathrm{C}$ & & & 2.00 p.m. & $30.0^{\circ} \mathrm{C}$ & $33.5^{\circ} \mathrm{C}$ \\
\hline & \multirow{2}{*}{ 7.8.2017 } & 8.00 a.m. & $21.3^{\circ} \mathrm{C}$ & $27.0^{\circ} \mathrm{C}$ & -0 & \multirow{2}{*}{ 7.8.2017 } & 8.00 a.m. & $21.3^{\circ} \mathrm{C}$ & $27.0^{\circ} \mathrm{C}$ \\
\hline & & 2.00 p.m. & $35.5^{\circ} \mathrm{C}$ & $59.1^{\circ} \mathrm{C}$ & ك. & & 2.00 p.m. & $33.5^{\circ} \mathrm{C}$ & $38.1^{\circ} \mathrm{C}$ \\
\hline
\end{tabular}

The greenery on the parking lot played a key role in preventing the overheating of the vehicle cabin. The temperature in the cabin of the vehicles parked in greened parking lot L2, measured at 2.00 p.m., was always significantly lower than the temperature in lot L1 without shading. To avoid the overheating of a vehicle cabin, it seems vital to provide shading during whole parking time. Such a prerequisite was adopted and implemented in the second stage of the research, which was modelling the greenery in lot L1 to improve temperature-related conditions. 


\subsection{Modelling the Greenery at $P+R$ Barje (L1)}

The central part of the study dealt with the design and comparison of different variants of greenery distribution at L1. By producing advanced 3D and 4D numerical models with the software tools ENVI-met and LEONARDO (Table 2), we evaluated the parking lot against the areas of optimal outdoor comfort and minimum environmental damage caused by the designed solutions.

Table 2. Input data of the study area in ENVI-met ${ }^{1}$.

\begin{tabular}{cc}
\hline \multicolumn{1}{c}{ Input Data } & \\
\hline Latitude and longitude & $46-14.5$ \\
Time zone & $(\mathrm{GMT}+2)$ \\
Start and duration of simulation & $05: 00 ; 24 \mathrm{~h}$ \\
Date of simulation & $29 / 6 / 2018$ \\
Wind speed at a height of $2 \mathrm{~m}$ & $1.1 \mathrm{~m} / \mathrm{s}$ \\
Wind direction & $225^{\circ}$ \\
Min. air temperature at a height of $2 \mathrm{~m}$ & $15^{\circ} \mathrm{C}$ \\
Max. air temperature at a height of $2 \mathrm{~m}$ & $29^{\circ} \mathrm{C}$ \\
Relative air humidity at a height of $2 \mathrm{~m}$ & $62^{\circ}$ \\
Tree model albedo & A generic-deciduous-tree \\
Tree ID & $01 \mathrm{CMSS}$ \\
Canopy geometry (m) & $3 \times 3 \times 5$ \\
Tree albedo & 0.12 \\
SPACES wall model & Generic wall \\
Wall ID & $100 \mathrm{MI}$ \\
Type of green areas & mixed substratum \\
Greening ID & $01 \mathrm{AGDS}$ \\
Green wall albedo & 0.2 \\
\hline
\end{tabular}

${ }^{1}$ Further information is provided in more detail in Section 2.4.

To control the relevance of shading and the temperature, we selected the date of 29 June, 2018 as the first measurement day at both L1 and L2 locations. Being close to the annual solstice, the angle of incidence of solar radiation was high on this day. The decrease of the angle in the following days was considered more favorable for shading by greenery. The initial analysis provided an insight into modelling possibilities and helped to hypothesize alternative planting systems, the position of green surfaces, and the use of shading bodies. A comparative analysis of designed greening models allowed us to determine the optimal shading of the parking lot and, consequently, to reduce the maximum surface and air temperature of the parking area at the height of $1.2 \mathrm{~m}$.

In the outcome of the modelling process were four solutions for greening (Figure 4). In three of these, the existing functional organization of the parking lot was preserved (Models A, C, and D), while in Model B, the layout was changed but the number of parking places remained unchanged.

In terms of greening elements, the modelling included trees with different layouts and vertical green walls with different orientations.

The main tasks in defining four diverse models were to ensure that the position of the inserted greening elements did not impact the capacity of the parking area, and to examine how their shadow changed throughout the day. Therefore, the adjustment of the position of greening elements did not impact the organizational quality of the parking lot, but it did cause changes in the air temperature.

By comparing the used greening elements-trees vs. green walls-we found that a tree provided better conditions for creating shade, while a green wall allowed a more effective temperature decrease in the parking lot, at the height of $1.2 \mathrm{~m}$. 


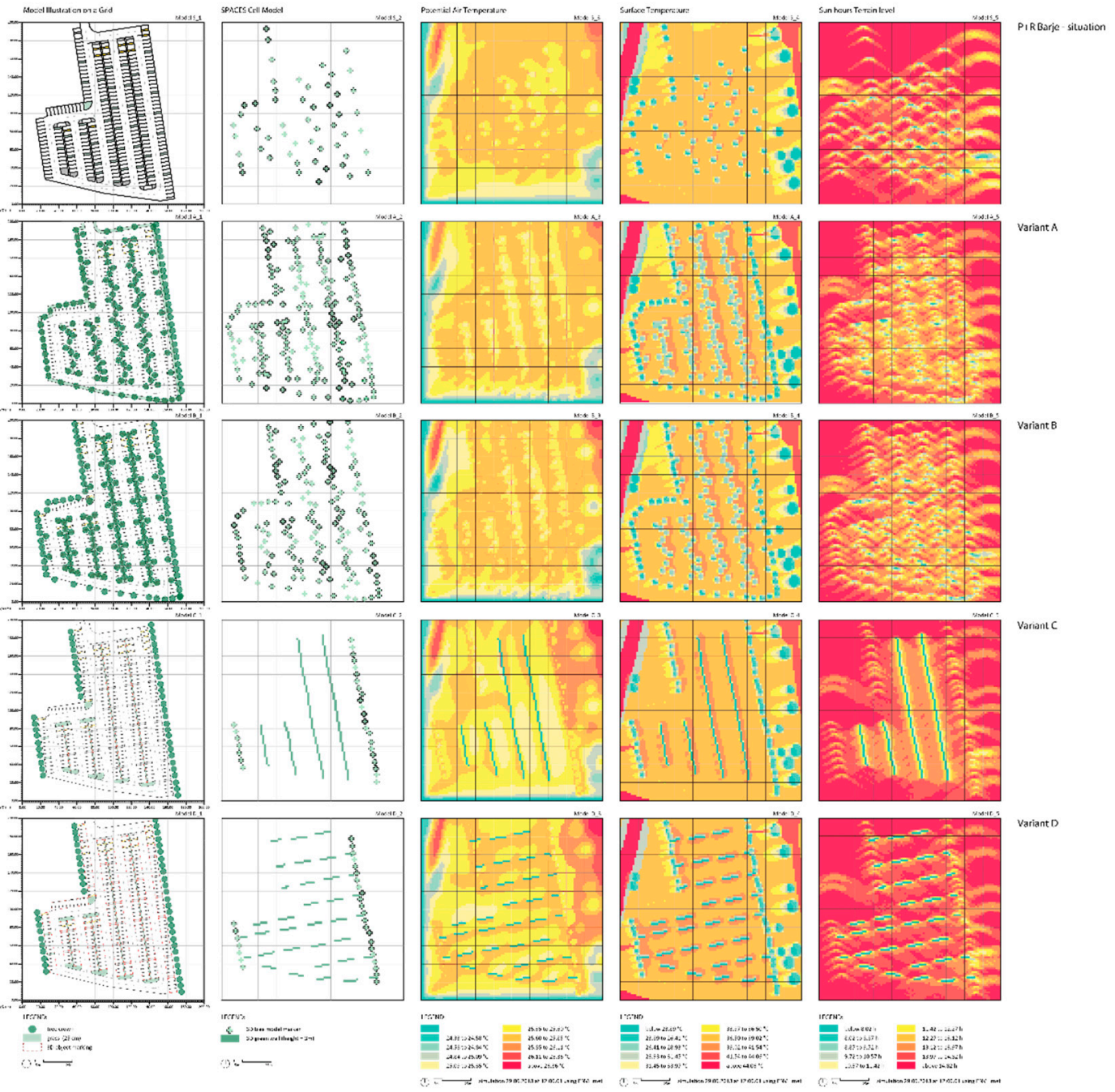

Figure 4. Models of urban greenery at P $+\mathrm{R}$ Barje (L1).

The designed models (Figure 4, Tables 3 and 4) featured the following:

- Model S stands for the current situation at site L1. We included trees (44) that were there in 2018 and are still there now (May 2020). Model S2 did not include the existing large trees outside L1; however, the model detected them (there was, however, no direct impact on the shading, depiction Model S3, while there was an impact on temperatures in Model S4).

- Model A presents the variant of tree densification in direction N-S (between the individual lines of parking). Trees in the E-W direction were added. The parking design affected the reorganization of the individual parking areas, which was still five parking spaces per unit. In Model A5 (in Table 5), we see that the shading was distributed evenly, meaning that there were several quality conditions of shading the parking areas. According to Model A3, we found that higher temperatures were evenly distributed across the parking area. This was the result of an increased number of trees and airflow stabilization. In this case, the number of trees did not bring about a reduction in temperatures.

- Model B also presents the variant of tree densification in the N-S direction, but with additional trees along a zigzagging line, with one tree per five parking spaces, switching to the East and West orientation. The design of the parking was not affected by this; the parking spaces remained organized in groups of five. The variant had an interesting composition, but in the horizontal direction, it created major islands without trees (compared to Model A), causing less favorable shading with trees and a poorer distribution of quality parking spaces. 
- Model C involved green walls between the parking lines in a N-S direction. The design of the parking remained the same, while a passage between the groups of five parking spaces must be provided. The model confirmed the thesis that green walls favorably affect air temperatures; however, in the sense of creating well-shaded parking areas (Model C5), it was less effective than Model A5 and B5. Interestingly, with this positioning, we managed to avoid all the worst shading positions. This variant also significantly affected the lowering of temperatures as, compared to Model A and B, the temperatures were, on average, lower by $2{ }^{\circ} \mathrm{C}$.

- Model D was an organization variant of the parking area, with walls installed in the $\mathrm{E}-\mathrm{W}$ direction. The parking area design was not changed with this; the discontinuity of the green wall between the groups of five parking spaces was not necessary. The model negated the vision of the significance of green walls, as shades in Model D5 were positioned the worst compared to all the previous models. The importance of the orientation of the greening element related to the rate of sunshine (sun hours) was confirmed. Air temperatures were less favorable in Model D3 than in Model C and Model C3 (which was related to the element of the green wall in N-S orientation).

Table 3. Parking unit Sun Hours simulation in ENVI-met ${ }^{1}$.

\begin{tabular}{|c|c|c|c|c|c|}
\hline $\begin{array}{l}\text { Variant } \\
\text { Name }\end{array}$ & $\begin{array}{l}\text { Variant ID } \\
\text { Tag }\end{array}$ & $\begin{array}{c}\text { Sun Hours } \\
\text { (Terrain Level) }\end{array}$ & $\begin{array}{c}\text { Number of } \\
\text { Parking Units }\end{array}$ & $\begin{array}{l}\text { Sun Hours } \\
\text { Area }\left(\mathrm{m}^{2}\right)\end{array}$ & $\begin{array}{l}\text { Combined Shade } \\
\text { Footprint }\left(\mathrm{m}^{2}\right) 2-10 \mathrm{~h}\end{array}$ \\
\hline \multirow{5}{*}{ Situation } & \multirow{5}{*}{ 5S_UHI } & below $8.87 \mathrm{~h}$ & 2 & 25 & \multirow{5}{*}{2312} \\
\hline & & 8.87 to $10.57 \mathrm{~h}$ & 30 & 375 & \\
\hline & & 10.57 to $12.27 \mathrm{~h}$ & 60 & 750 & \\
\hline & & 12.27 to $13.97 \mathrm{~h}$ & 93 & 1162.5 & \\
\hline & & above $13.97 \mathrm{~h}$ & 82 & 1025 & \\
\hline \multirow{5}{*}{ Model A } & \multirow{5}{*}{ 5A_UHI } & below $8.87 \mathrm{~h}$ & 2 & 25 & \multirow{5}{*}{2987} \\
\hline & & 8.87 to $10.57 \mathrm{~h}$ & 43 & $537.5^{*}$ & \\
\hline & & 10.57 to $12.27 \mathrm{~h}$ & 141 & $1762.5^{*}$ & \\
\hline & & 12.27 to $13.97 \mathrm{~h}$ & 53 & 662.5 & \\
\hline & & above $13.97 \mathrm{~h}$ & 28 & 350 & \\
\hline \multirow{5}{*}{ Model B } & \multirow{5}{*}{ 5B_UHI } & below $8.87 \mathrm{~h}$ & 16 & $200 *$ & \multirow{5}{*}{2900} \\
\hline & & 8.87 to $10.57 \mathrm{~h}$ & 39 & 487.5 & \\
\hline & & 10.57 to $12.27 \mathrm{~h}$ & 92 & 1150 & \\
\hline & & 12.27 to $13.97 \mathrm{~h}$ & 85 & 1062.5 & \\
\hline & & above $13.97 \mathrm{~h}$ & 35 & 437.5 & \\
\hline \multirow{5}{*}{ Model C } & \multirow{5}{*}{ 5C_UHI } & below $8.87 \mathrm{~h}$ & 0 & 0 & \multirow{5}{*}{2700} \\
\hline & & 8.87 to $10.57 \mathrm{~h}$ & 19 & 237.5 & \\
\hline & & 10.57 to $12.27 \mathrm{~h}$ & 82 & 1025 & \\
\hline & & 12.27 to $13.97 \mathrm{~h}$ & 115 & 1562.5 * & \\
\hline & & above $13.97 \mathrm{~h}$ & 51 & 512.5 & \\
\hline \multirow{5}{*}{ Model D } & \multirow{5}{*}{ 5D_UHI } & below $8.87 \mathrm{~h}$ & 13 & 162.5 & \multirow{5}{*}{1312} \\
\hline & & 8.87 to $10.57 \mathrm{~h}$ & 28 & 350 & \\
\hline & & 10.57 to $12.27 \mathrm{~h}$ & 8 & 100 & \\
\hline & & 12.27 to $13.97 \mathrm{~h}$ & 56 & 700 & \\
\hline & & above $13.97 \mathrm{~h}$ & 162 & $2025 *$ & \\
\hline
\end{tabular}

${ }^{1}$ The number of parking units is 267 for all simulated variants. One parking space size measures $12.5 \mathrm{~m}^{2}$. The total area of all parking spaces combined is $3337.5 \mathrm{~m}^{2}$. The combined shade footprint values areas that receive shade for a maximum of 10 and a minimum of $2 \mathrm{~h}$ a day. This equals sun hours up to $13.97 \mathrm{~h}$. $\left(^{*}\right)$ marks the highest values of sun hours for each category value. 
Table 4. Parking unit Potential Air Temperature simulation in ENVI-met ${ }^{2}$.

\begin{tabular}{|c|c|c|c|c|}
\hline $\begin{array}{l}\text { Variant } \\
\text { Name }\end{array}$ & $\begin{array}{l}\text { Variant ID } \\
\text { Tag }\end{array}$ & $\begin{array}{l}\text { Potential Air } \\
\text { Temperature }\end{array}$ & $\begin{array}{c}\text { Number of } \\
\text { Parking Units }\end{array}$ & $\begin{array}{l}\text { Parking Units } \\
\text { Area }\left(\mathrm{m}^{2}\right)\end{array}$ \\
\hline \multirow{5}{*}{ Situation } & \multirow{5}{*}{ 5S_UHI } & below $24.33^{\circ} \mathrm{C}$ & 0 & 0 \\
\hline & & $24.33^{\circ} \mathrm{C}$ to $25.09^{\circ} \mathrm{C}$ & 0 & 0 \\
\hline & & $25.09^{\circ} \mathrm{C}$ to $25.85^{\circ} \mathrm{C}$ & 74 & 925 \\
\hline & & $25.85^{\circ} \mathrm{C}$ to $26.36^{\circ} \mathrm{C}$ & 177 & 2212.5 \\
\hline & & above $26.36{ }^{\circ} \mathrm{C}$ & 16 & 200 \\
\hline \multirow{5}{*}{ Model A } & \multirow{5}{*}{ 5A_UHI } & below $24.33^{\circ} \mathrm{C}$ & 0 & 0 \\
\hline & & $24.33^{\circ} \mathrm{C}$ to $25.09^{\circ} \mathrm{C}$ & 0 & 0 \\
\hline & & $25.09^{\circ} \mathrm{C}$ to $25.85^{\circ} \mathrm{C}$ & 64 & 800 \\
\hline & & $25.85^{\circ} \mathrm{C}$ to $26.36^{\circ} \mathrm{C}$ & 168 & 2100 \\
\hline & & above $26.36^{\circ} \mathrm{C}$ & 35 & 437.5 \\
\hline \multirow{5}{*}{ Model B } & \multirow{5}{*}{ 5B_UHI } & below $24.33^{\circ} \mathrm{C}$ & 0 & 0 \\
\hline & & $24.33^{\circ} \mathrm{C}$ to $25.09^{\circ} \mathrm{C}$ & 0 & 0 \\
\hline & & $25.09^{\circ} \mathrm{C}$ to $25.85^{\circ} \mathrm{C}$ & 72 & 900 \\
\hline & & $25.85^{\circ} \mathrm{C}$ to $26.36^{\circ} \mathrm{C}$ & 153 & 1912.5 \\
\hline & & above $26.36^{\circ} \mathrm{C}$ & 42 & 525 \\
\hline \multirow{5}{*}{ Model C } & \multirow{5}{*}{ 5C_UHI } & below $24.33^{\circ} \mathrm{C}$ & 9 & 112.5 \\
\hline & & $24.33^{\circ} \mathrm{C}$ to $25.09^{\circ} \mathrm{C}$ & 10 & 1250 \\
\hline & & $25.09^{\circ} \mathrm{C}$ to $25.85^{\circ} \mathrm{C}$ & 233 & 2912.5 \\
\hline & & $25.85^{\circ} \mathrm{C}$ to $26.36^{\circ} \mathrm{C}$ & 15 & 187.5 \\
\hline & & above $26.36{ }^{\circ} \mathrm{C}$ & 0 & 0 \\
\hline \multirow{5}{*}{ Model D } & \multirow{5}{*}{ 5D_UHI } & below $24.33^{\circ} \mathrm{C}$ & 4 & 50 \\
\hline & & $24.33^{\circ} \mathrm{C}$ to $25.09^{\circ} \mathrm{C}$ & 28 & 350 \\
\hline & & $25.09^{\circ} \mathrm{C}$ to $25.85^{\circ} \mathrm{C}$ & 182 & 2275 \\
\hline & & $25.85^{\circ} \mathrm{C}$ to $26.36^{\circ} \mathrm{C}$ & 48 & 600 \\
\hline & & above $26.36{ }^{\circ} \mathrm{C}$ & 5 & 625 \\
\hline
\end{tabular}

2 The number of parking units is 267 for all simulated variants. One parking space size measures at $12.5 \mathrm{~m}^{2}$. The total area of all parking spaces combined is $3337.5 \mathrm{~m}^{2}$.

Table 5. Greening scheme.

\begin{tabular}{|c|c|c|c|c|c|c|c|}
\hline \multicolumn{8}{|c|}{ Greening Scheme } \\
\hline & $\begin{array}{l}\text { Border } \\
\text { Cond. V. }\end{array}$ & $\begin{array}{c}\text { Border } \\
\text { Cond. H. }\end{array}$ & $\begin{array}{c}\text { Vertical } \\
\text { Distance } \\
\text { between } \\
\text { Parking Units }\end{array}$ & $\begin{array}{c}\text { Horizontal } \\
\text { Distance } \\
\text { between } \\
\text { Parking Units }\end{array}$ & $\begin{array}{l}\text { Comparable } \\
\text { Unit in } \\
\text { Length }\end{array}$ & $\begin{array}{c}\text { Unit m² } \\
\text { (Green } \\
\text { Area) }\end{array}$ & $\begin{array}{c}\text { Unit m}^{2} \\
\text { (Green } \\
\text { Wall) }\end{array}$ \\
\hline Model S ${ }^{3}$ & 11 & 4 & $\mathrm{n} / \mathrm{o}$ & $43^{*}$ & 3 & 24 & - \\
\hline Model A & $21+27$ & $11+6$ & sum 60 & $48+13$ & 16 & 112.6 & - \\
\hline Model B & $21+27$ & $11+10$ & sum 23 & $47+11$ & 11 & 106 & - \\
\hline Model C & $21+27$ & $\mathrm{n} / \mathrm{o}$ & - & - & - & 82.5 & 120 \\
\hline Model D & $21+27$ & $\mathrm{n} / \mathrm{o}$ & - & - & - & 82.5 & 174 \\
\hline Model X & $21+22$ & $\mathrm{n} / \mathrm{o}$ & sum 60 & 2 & 11 & 119 & - \\
\hline
\end{tabular}

${ }^{3}$ To give a clear illustration of the parking area organization, trees are not plotted in 1 s (verified in the field and evident from Google Earth).

Model X (Figure 5). The assessment of the results included the significance of a different kind of designing $\mathrm{P}+\mathrm{Rs}$ by offsetting the position of roads at an angle of $5^{\circ}-10^{\circ}$ and the inclusion of larger green areas in-between (Figure 5), providing better tree growth and the possibility of tree densification (comparison in Table 5, Figure 6). 


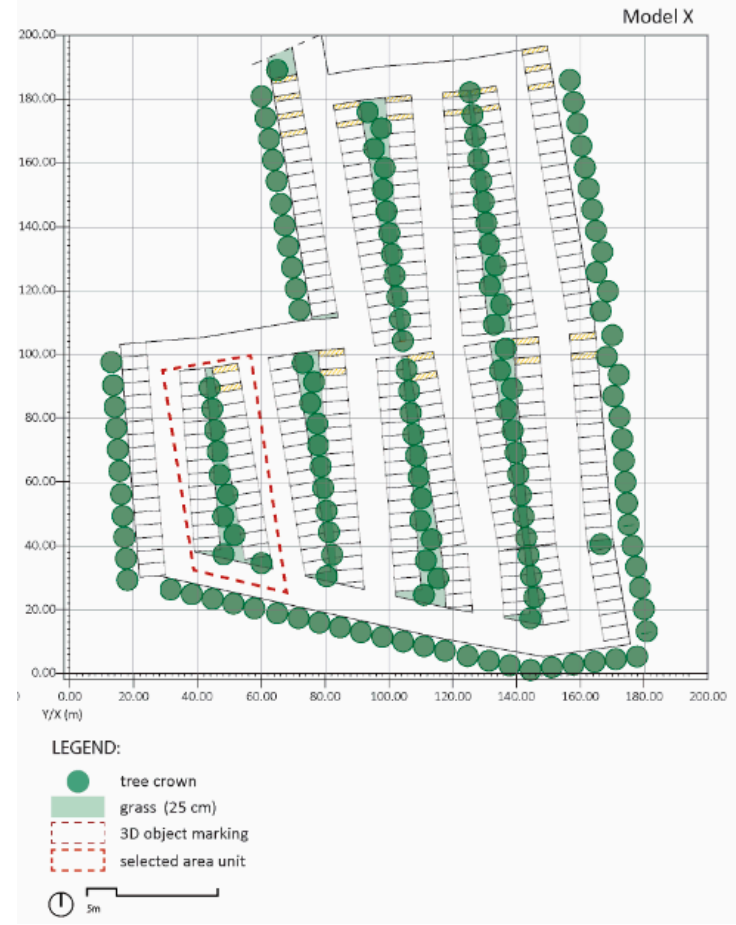

Figure 5. Model X.
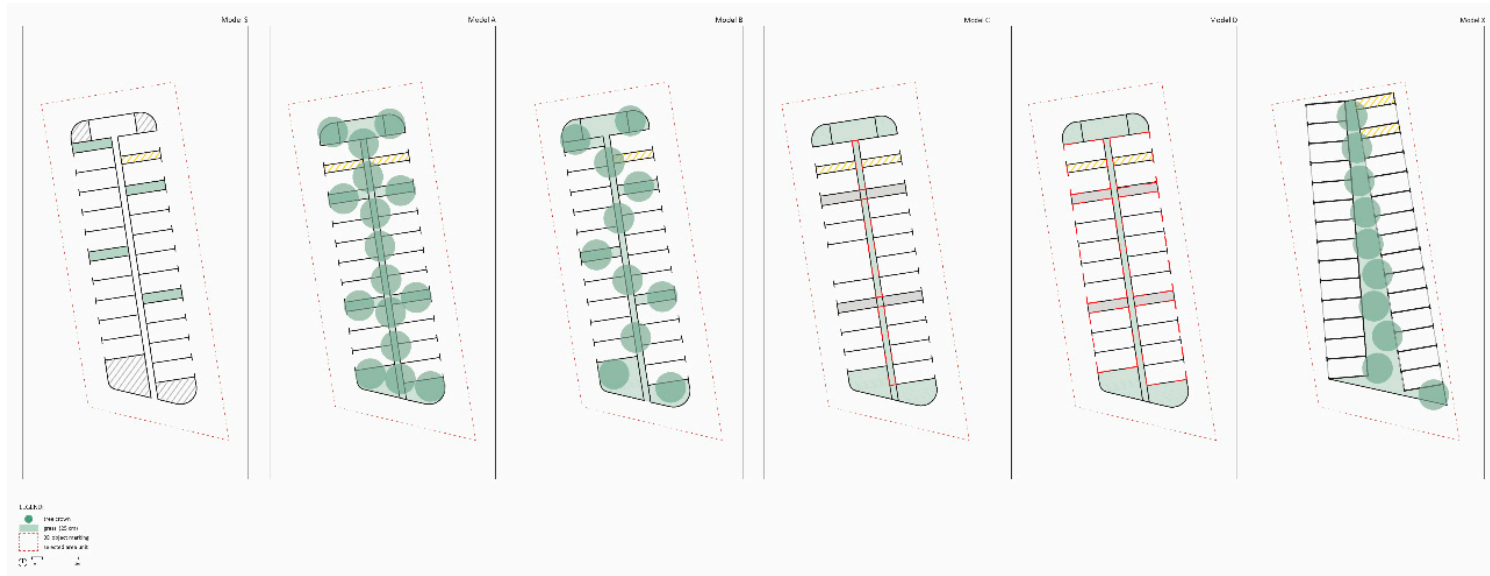

Figure 6. Greening-Comparable unit.

\section{Discussion}

Further evaluation and optimization of the developed models can be done on the basis of the "aesthetics," "amenity," and "shading benefits" that were explained by Nieuwenhuijsen [46] in the context of urban and transport planning for livable and healthy cities as elements that "have also been shown to provide significant economic benefits, while benefits in terms of water regulation, carbon reduction and air quality are usually more modest" [47].

To assess the visual quality of the derived variants, trees and living walls on the parking lot and trees as a boundary condition should all be taken into consideration. Two main assessment principles can be established: the level of the visual perception of the parking lot from afar, and the level of the visual perception of the belonging parking system-i.e., the density of greening elements. Following these criteria, it can be concluded that densely green Model A and B (Figure 4; Models A1 and B1) interrupt the visual continuity, but at the same time offer a pleasant feeling. Models C and $\mathrm{D}$ provide for the inclusion of the green wall element, which is of interest in terms of composition, but does not improve shading. Model C is approaching the values of shading Models A and B 
(Figure 4-Models A5, B5, and C5); however, in terms of area perception, this implies restricted visual contacts. According to all the conditions investigated, Model D is the worst variant, even though the position of elements in the $\mathrm{E}-\mathrm{W}$ direction allows for a visual connection when approaching the $\mathrm{P}+\mathrm{R}$ (the access road is in the N-S direction). Even though the green wall is interesting, it is, in fact, less suitable in terms of maintenance. For discussion reasons, we added Model X, which offers tree densifications, creating the perception of green/forest islands. Model X does not follow the existing parking area design (the starting condition in the study was the existing design); nevertheless, it is important in the sense of comparing green areas and the number of trees. The tree concentration is suitable; however, the (non-functional) driving dynamics is put under question. Shading brings an added aesthetic value to a $\mathrm{P}+\mathrm{R}$ facility, as it positively affects the perception of space under extreme heat. Models A and B offer the most shaded areas; from the point of view of a visual continuity, it would be recommended to remove the trees representing the boundary conditions of the site. Given the number of trees and considering all the criteria, Model B is the most rational one and gives an added value to the artistic organization of the green element.

In this study, we addressed the thermal comfort level related to the rise in temperatures inside vehicles parked at a $\mathrm{P}+\mathrm{R}$ facility and the threats to health and drivers' psychophysical performance. Moreover, it is important to understand the interplay of the results given in Figure 4 with temperatures and shading. The sense of ventilation, airiness, tree density, etc., are the elements that affect the comfort level at a P $+\mathrm{R}$ facility. It is necessary to explain that all these elements decrease the temperatures on the ground (as indicated by the models); however, trees are three times more beneficial than other green elements. The aforementioned elements and model depictions confirm the positive roles of Models $A$ and $B$, but with restrictions referring to tree density and the visual significance of the $P+R$ role, which is not a green area, per se.

Adequate green elements introduced in an open parking area not only provide shade and prevent the overheating of parked vehicles, but also contribute to the reduction of the outdoor air temperature due to evaporation. The temperature values of the areas shaded in vegetation were perceived as the most comfortable in Model C (Figure 4, Model C5). Nevertheless, given the progression of shading, we find that the green wall as a shading element present in this, as well as in Model D, does not adequately support the $\mathrm{P}+\mathrm{R}$ organization. Furthermore, shading by a green wall does not affect a person in the way that a cool tree canopy would (it is more like shading provided by a building). The most favorable natural shading element would be a pergola, which would cover the whole parking area and, thus, provide permanent shading. However, it is necessary to note that this decreases the significance of the elements presented in Sections 3.1 and 3.2 of this paper.

Overall, given the primary function of an open parking area, this study demonstrated the need for optimization between the capacity and organization of a parking lot, on the one hand, and the type and spatial distribution of green elements that provide shading, on the other. In the existing parking area $\mathrm{P}+\mathrm{R}$ Barje, the trees were identified as the most important element in providing shading in the variant when the shading is provided between parking spaces.

\section{Conclusions}

This study revealed the interrelations between the greenery in open parking areas, the temperature inside parked vehicles, and the local UHI effect. This study was conceptualized as two-stage research. The first (preliminary) stage dealt with the measurement and analysis of temperature data at two nearby open parking lots in the city of Ljubljana, one of which was the main research spatial area ( $P+R$ Barje, L1), and the other (Trnovo parking, L2) was used for comparison. The second phase of the study was dedicated to modelling the greenery at the principal location L1. Accordingly, the presentation of findings in this paper referred separately to each of the two stages. Progressive result generation allows for adjustments and, thus, enables a wider application of the designed research methodology.

Like most European capitals, Ljubljana is susceptible to the manifestation of UHI [15]. While urban morphology initially influences the occurrence and intensity of UHI, ultimate consequences are felt by 
the users of the space. As demonstrated in this paper on the example of two nearby open parking locations in Ljubljana that were similar in all parameters except for the density of the greenery, the UHI effect is more intensive on the lot characterized by sealed artificial surface and scarce greenery (location L1), in spite of adjacent natural green areas. Likewise, the temperature in the cabin of the vehicle parked at location L1 was significantly higher in comparison with location L2, which had sufficient greenery to provide constant shade to parked vehicles.

Parking the vehicles in the open space during the warmer part of the year can easily result in the overheating of the cabin, especially when the duration of parking time is longer. The measurements showed that parking on an open surface without solar protection raises the temperature in the cabin to such an extent that it becomes dangerous for the health of the driver and other passengers in the vehicle, but also for traffic safety. For illustration, on the warmest day of measurement period, when outdoor air temperature was $35.5^{\circ} \mathrm{C}$, the temperature of the air in the vehicle cabin rose to $59.1^{\circ} \mathrm{C}$. High air temperatures in vehicles were measured also during moderately hot sunny days, which was also found by other authors [22,23].

The key measure to prevent overheating in the cabin of the vehicle parked in an open space is shading. Though the shade can be produced by natural (e.g., trees) and man-made objects (e.g., the overhang) [21], greenery offers far more benefits: inter alia, the reduction of the aforementioned UHI effect [6-10]. Therefore, shading by greenery was adopted in this paper as the strategy aimed at improving the conditions by modelling different variants of greening parking lot L1.

Another important input to modelling was the fact that the vehicle must be parked in shade at all times, without (even short-term) exposure to direct sunlight. The desired state currently represents a challenge to $\mathrm{P}+\mathrm{R}$ lots in many European cities. To that end, a transitional practical solution could concern the categorization of individual parking places according to the estimated length of parking time. In research terms, the continuation of the presented study could deal with the length of time during which the indoor air temperature of a vehicle parked in an open space rises above the recommended thresholds, examined against various shading-related conditions. An alternative research direction that would help to strengthen the validity of the obtained results refers to the in-depth analysis of drivers' behavior at open $\mathrm{P}+\mathrm{R}$ surfaces in terms of selecting a parking place, and the practice of precooling the vehicle cabin before leaving the parking area.

Author Contributions: Conceptualization, A.F. and M.Z.-S.; Data curation, M.Z.-S.; Formal analysis A.F. and K.L.; Investigation, A.F. and K.L.; Methodology, A.F., M.Z.-S., and S.K.; Project administration, K.L. and J.P.G.; Supervision A.F.; Visualization K.L. and J.P.G.; Writing-Original draft, A.F., M.Z.-S., and S.K.; Writing一Review and editing, A.F. All authors have read and agreed to the published version of the manuscript.

Funding: This research was funded by Slovenian Research Agency, by the Research Programme "Sustainable planning for the quality living space", no. P5-0068.

Conflicts of Interest: The authors declare no conflict of interest.

\section{References}

1. De la Barrera, F.; Henríquez, C. Monitoring the change in urban vegetation in 13 Chilean cities located in a rainfall gradient. What is the contribution of the widespread creation of new urban parks? Conf. Ser. Mater. Sci. Eng. 2017, 245, 72023. [CrossRef]

2. McCarthy, M.P.; Best, M.J.; Betts, R.A. Climate change in cities due to globalwarming and urban effects. Geophys. Res. Lett. 2010, 37, 1-5. [CrossRef]

3. Arnds, D.; Böhner, J.; Bechtel, B. Spatio-temporal variance and meteorological drivers of the urban heat island in a European city. Theor. Appl. Climatol. 2015, 128, 43-61. [CrossRef]

4. Guerreiro, S.B.; Dawson, R.J.; Kilsby, C.; Lewis, E.; Ford, A. Future heat-waves, droughts and floods in 571. European cities. Environ. Res. Lett. 2018, 13, 034009. [CrossRef]

5. Smid, M.; Russo, S.; Costa, A.C.; Granell, C.; Pebesma, E. Ranking European capitals by exposure to heat waves and cold waves. Urban Clim. 2019, 27, 388-402. [CrossRef] 
6. De Roo, M.; Roozen, N. The Green City Guidelines. Techniques for a Healthy Liveable City; Zwaan Printmedia: Wormerveer, The Netherlands, 2011. Available online: http://aiph.org/wp-content/uploads/2015/04/Green\% 20City\%20-\%20Guidelines.pdf (accessed on 20 April 2020).

7. Oliveira, S.; Andrade, H.; Vaz, T. The cooling effect of green spaces as a contribution to the mitigation of urban heat: A case study in Lisbon. Build. Environ. 2011, 46, 2186-2194. [CrossRef]

8. Afzan Buyadi, S.N.; Wan Mohd, W.M.N.; Misni, A. Green Spaces Growth Impact on the Urban Microclimate. Procedia Soc. Behav. Sci. 2013, 105, 547-557. [CrossRef]

9. Huang, C.; Ye, X. Spatial Modeling of Urban Vegetation and Land Surface Temperature: A Case Study of Beijing. Sustainability 2015, 7, 9478-9504. [CrossRef]

10. Irman, H.M.; Kala, J.; Ng, A.W.M.; Muthukumaran, S. Effectiveness of vegetated patches as Green Infrastructure in mitigating Urban Heat Island effects during a heatwave event in the city of Melbourne. Weather. Clim. Extrem. 2019, 25, 1-14. [CrossRef]

11. Amani-Beni, M.; Zhang, B.; Xie, G.-D.; Shi, Y. Impacts of Urban Green Landscape Patterns on Land Surface Temperature: Evidence from the Adjacent Area of Olympic Forest Park of Beijing, China. Sustainability 2019, 11, 513. [CrossRef]

12. Lavtižar, K. Urban Design Embracing the Wind Environment: Bezigrad Neighbourhood Case Study in Ljubljana, Slovenia. Res. Ecol. 2020, 2, 23-31. [CrossRef]

13. Kosanović, S.; Fikfak, A. Development of criteria for ecological evaluation of private residential lots in urban areas. Energy Build. 2016, 115, 69-77. [CrossRef]

14. Čok, G. Residential buildings and sustainable development in Slovenia-Stambene zgrade i održivi razvoj u Sloveniji. Prostor 2014, 22, 134-147. Available online: http://hrcak.srce.hr/index.php?show=clanak\&id_ clanak_jezik=183572 (accessed on 10 April 2020).

15. Fikfak, A.; Kosanović, S.; Konjar, M.; Grom, J.P.; Zbašnik-Senegačnik, M. The impact of morphological features on summer temperature variations on the example of two residential neighborhoods in Ljubljana, Slovenia. Sustainability 2017, 9, 122. [CrossRef]

16. Mueller, N.; Rojas-Rueda, D.; Khreis, H.; Cirach, M.; Andresg, D.; Ballester, J.; Bartollh, X.; Daher, C.; Deluca, A.; Echaveg, C.; et al. Changing the urban design of cities for health: The superblock model. Environ. Int. 2020, 134, 1-13. [CrossRef]

17. Žaucer, T.; Suhadolc, M.; Prijon, J.; Jeriha, U.; Peterlin, M. P+R Lokacija, Oblikovanje, Oprema; Inštitut za Politike Prostora: Ljubljana, Slovenia, 2014. Available online: http://ipop.si/wp/wp-content/uploads/2010/04/ P+R-2016-05-30-lo-res.pdf (accessed on 10 January 2018).

18. Bajsanski, I.; Stojakovic, V.; Jovanovic, M. Effect of tree location on mitigating parking lot insolation. Comput. Environ. Urban Syst. 2016, 56, 59-67. [CrossRef]

19. O'Malley, C.; Piroozfarb, P.A.E.; Farr, E.R.P.; Gates, J. An investigation into minimizing urban heat island (UHI) effects: A UK perspective. Energy Procedia 2014, 62, 72-80. [CrossRef]

20. Srivanit, M.; Kazunori, H. The Influence of Urban Morphology Indicators on Summer Diurnal Range of Urban Climate in Bangkok Metropolitan Area, Thailand. Int. J. Civ. Environ. Eng. 2011, 11, 34-46. Available online: http://www.ijens.org/Vol_11_I_05/112805-7676-IJCEE-IJENS.pdf (accessed on 24 November 2016).

21. Venter, Z.S.; Krog, N.H.; Barton, D.N. Linking green infrastructure to urban heat and human health riskmitigation in Oslo, Norway. Sci. Total Environ. 2020, 709, 1-10. [CrossRef]

22. Grundstein, A.; Meentemeyer, V.; Dowd, J. Maximum vehicle cabin temperatures under different meteorological conditions. Int. J. Biometeorol. 2009, 53, 255-261. [CrossRef]

23. McLaren, C.; Null, J.; Quinn, J. Heat stress from enclosed vehicles: Moderate ambient temperatures causes significant temperature rise in enclosed vehicles. Pediatrics 2005, 116, e109-e112. Available online: https://pediatrics.aappublications.org/content/pediatrics/116/1/e109.full.pdf (accessed on 26 April 2020). [CrossRef]

24. Marty, W.T.; Sigrist, T.; Wyler, D. Temperature variations in automobiles in various weather conditions: An experimental contribution to the determination of time of death. Am. J. Forensic Med. Pathol. 2001, 22, 215-219. [CrossRef] [PubMed]

25. Lenzuni, P.; Capone, P.; Freda, D.; del Gaudio, M. Is driving in a hot vehicle safe? Int. J. Hyperther. 2014, 30, 250-257. [CrossRef] [PubMed]

26. Hancock, P.A.; Vasmatzidis, I. Effects of heat stress on cognitive performance: The current state of knowledge. Int. J. Hyperther. 2003, 19, 355-372. [CrossRef] [PubMed] 
27. Sun, G.; Yang, X.; Jiang, Q.; Liu, K.; Li, L. Hyperthermia impairs the executive function using the attention network test. Int. J. Hyperther. 2012, 28, 621-626. [CrossRef]

28. Wyon, D.P.; Wyon, I.; Norin, F. Effects of moderate heat stress on driver vigilance in a moving vehicle. Ergonomics 1996, 39, 61-75. [CrossRef]

29. Alavipanah, S.; Wegmann, M.; Qureshi, S.; Weng, Q.; Koellner, T. The Role of Vegetation in Mitigating Urban Land Surface Temperatures: A Case Study of Munich, Germany during the Warm Season. Sustainability 2015, 7, 4689-4706. [CrossRef]

30. Onishi, A.; Cao, X.; Ito, T.; Shi, F.; Imura, H. Evaluating the potential for urban heat-island mitigation by greening parking lots. Urban For. Urban Green. 2010, 9, 323-332. [CrossRef]

31. Gillner, S.; Vogt, J.; Tharang, A.; Dettmann, S.; Roloff, A. Role of street trees in mitigating effects of heat and drought at highly sealed urban sites. Landsc. Urban Plan. 2015, 143, 33-42. [CrossRef]

32. Statistical Office of the Republic of Slovenia. SI-Stat Data Portal. Available online: http://www.stat.si/eng/ index.asp (accessed on 29 April 2020).

33. European Commission. Environment, European Green Capital. Available online: https://ec.europa.eu/ environment/europeangreencapital/winning-cities/2016-ljubljana/ (accessed on 29 April 2020).

34. City of Ljubljana. Integrated Transport Strategy. Available online: https://www.ljubljana.si/sl/moja-ljubljana/ promet-in-mobilnost/javni-prevoz/ (accessed on 21 June 2020).

35. City of Ljubljana. P+R Parkings. Available online: https://www.ljubljana.si/sl/moja-ljubljana/ljubljana-zate/ pregled-vseh-projektov/parkirisca-p-r/ (accessed on 21 June 2020).

36. Ministry of Environment and Spatial Planning, Surveying and Mapping Authority of the Republic of Slovenia. E-Suraying Data. Available online: https://www.gov.si/en/state-authorities/bodies-withinministries/surveying-and-mapping-authority/ (accessed on 25 April 2020).

37. USGS Science for a Changing World. Landsat Missions. Available online: https://www.usgs.gov/landresources/nli/landsat (accessed on 10 April 2020).

38. Google Maps. Available online: https://www.google.si/maps (accessed on 6 April 2020).

39. ENVI-Met. Available online: https://www.envi-met.com/ (accessed on 28 April 2020).

40. Chatzinikolaou, E.; Chalkias, C.; Dimopoulou, E. Urban microclimate improvement using ENVI-met climate model. Int. Arch. Photogramm. Remote Sens. Spatial Inf. Sci. 2018, 42, 69-76. [CrossRef]

41. Bruse, M. Die Auswirkungen kleinskaliger Umweltgestaltung auf das Mikroklima. Entwicklung des Prognostischen Numerischen Modells ENVI-met zur Simulation der Wind-, Temperatur- und Feuchteverteilung in Stadtischen Strukturen. Ph.D. Thesis, Ruhr-Universität, Bochum, Germany, 1999.

42. Ministry of the Environment and Spatial Planning; Slovenian Environmental Agency. Meteorološke Postaje Ljubljana Bežigrad. Available online: https://meteo.arso.gov.si/met/en/ (accessed on 28 April 2020).

43. Cegnar, T. Podnebne razmere v juniju 2018. Naše Okolje 2018, 6, 3. Available online: https://www.arso.gov. si/o\%20agenciji/knji\%c5\%benica/mese\%c4\%8dni\%20bilten/NASE\%20OKOLJE\%20-\%20Junij\%202018.pdf (accessed on 28 April 2020).

44. Cegnar, T. Podnebne razmere v juliju 2018. Naše Okolje 2018, 7, 3. Available online: https://www.arso.gov.si/o\% 20agenciji/knji\%c5\%benica/mese\%c4\%8dni\%20bilten/NASE\%20OKOLJE\%20-\%20Julij\%202018.pdf (accessed on 28 April 2020).

45. Cegnar, T. Podnebne razmere v juliju 2018. Naše Okolje 2018, 8, 3. Available online: https://www.arso.gov.si/ o\%20agenciji/knji\%c5\%benica/mese\%c4\%8dni\%20bilten/NASE\%20OKOLJE\%20-\%20Avgust\%202018.pdf (accessed on 28 April 2020).

46. Nieuwenhuijsen, M.J. Urban and transport planning pathways to carbon neutral, liveable and healthy cities; A review of the current evidence. Environ. Int. 2020. [CrossRef]

47. Song, X.P.; Tan, P.Y.; Edwards, P.; Richards, D. The economic benefits and costs of trees in urban forest stewardship: A systematic review. Urban For. Urban Green. 2018, 29, 162-170. [CrossRef]

(C) 2020 by the authors. Licensee MDPI, Basel, Switzerland. This article is an open access article distributed under the terms and conditions of the Creative Commons Attribution (CC BY) license (http://creativecommons.org/licenses/by/4.0/). 